\title{
Strategic Management in the Hotel Industry: Proposed Strategic Practices to Recover from COVID- 19 Global Crisis
}

\author{
Belias Dimitrios ${ }^{1}$ \\ Papademetriou Christos $^{2}$ \\ Rossidis Ioannis 3 \\ Labros Vasiliadis ${ }^{4}$ \\ ${ }^{1}$ Ass. Professor, PhD, Department of Business Administration, \\ University of Thessaly, Larissa, Geopolis, Greece \\ ${ }^{2}$ Lecturer, PhD, Department of Economics and Business, \\ Neapolis University Pafos, Cyprus; Corresponding Author \\ ${ }^{3}$ Lecturer, PhD, University of the Peloponnese, \\ Tripolis, Campus, Greece \\ ${ }^{4}$ Ass. Professor, PhD, General Department for \\ National and Kapodistrian University of Athens, Greece
}

DOI: https://doi.org/10.36941/ajis-2020-0117

\section{Abstract}

Hotel companies operate in a highly competitive environment, targeting much clientele from the international market with many specialties. The management in these too demanding conditions is called upon to apply modern strategic management practices by analyzing global developments and supporting the decisionmaking process by limiting the uncertainty created by the external environment. In this context, it is imperative to analyze the financial and administrative impact of COVID-19, which strongly threatens tourist traffic and largely overturning current budget estimations. Strategic management can make a decisive contribution to addressing this threat by adopting the established business strategy. This article is based on similar past crises, as they were faced with strategic tools. This work aims to discuss and present the most appropriate recovery management strategies, which can help the hotel industry respond to this unprecedented crisis.

Keywords: Strategic Management, Hotel Management, Global Crises, COVID-19, Recovery

\section{Introduction}

Unquestionably, weather alteration, and natural disasters in some touristic countries will be critical components in damagingly affecting tourism flows in the short term (Mather et al., 2005). In the same vein, according to Ryan (2003), unexpected worldwide financial crises may considerably reduce travel mobility since it is a factor influencing the international economic request for tourism. Moreover, terrorist attacks like in New York in 2001, in Bali in 2002, in Madrid in 2004, and London in 2005, can all significantly impact the global tourism industry sector (Page and Connell, 2006).

Additional to natural, economical, and security elements, worldwide public health worries have 
become a vital component affecting the tourism sector. International epidemics and contagious viruses have had a significant impact on the tourism industry. According to Mason et al. (2005), these health infections such as Sars, Mers, $\mathrm{H}_{1} \mathrm{~N}_{1}$ have crucial economic implications and, therefore, negatively affect the tourism sector. Nowadays, humanity is called to face another international health threat, the COVID- 19 .

The COVID- 19 pandemic is both a humanitarian crisis affecting people's lives and a tremendous economic crisis. World Travel and Tourism Council (2020) estimates that the impact of this crisis on tourism will be five times that of the global financial crisis. Hence, the tourism industry has to adopt a series of measures to have a rapid recovery. Strategic management can play a tremendous role in overcoming this crisis.

The strategy is a concept that is widely used today. The idea of strategic management began from big business and has evolved into the entire administration currently used in the organization and companies such as non-profit and cultural organizations. The strategy is used because it leads to effective strategic management, which is related to the fact that organizations operate today requires decisions that will help the organizations address the challenges they are facing effectively and efficiently.

The strategy is a rational way of planning an organization's movements to take advantage of the opportunities and threats it will encounter in its environment (Ansoff et al., 2018).

As mentioned above, strategic management has been started by companies, but soon expanded to other organizations, including hotels. Indeed, hotels today have to operate in a very demanding harsh environment; hence they need strategies and strategic tools which are made especially for this industry (Okumus et al., 2018). According to Abu Bakar et al. (2011: 140), "strategic management is a concept that concerns are making decisions and taking corrective actions to achieve long term targets and goals of an organization." Currently, the tourist industry has to face the COVID- 19 crisis. Strategic management's importance lies in the fact that it should promote a comprehensive strategy to guide the hotel industry towards recovery. This is new, which means a lack of significant theories and case studies recommending potentially successful strategic tools. This paper will fill this gap by researching the most important strategic tools that can lead a hotel to overcome this critical period.

\section{Literature Review}

It is generally accepted, that the word "strategy" is originated from both the word "stratum", in other words course or way, and the word "strategos" which refers to the ancient Greek general Strategos (Eren, 2006). According to Aktan (2009), the word strategy is used for many years now as a military term in order to describe the knowledge and approach of the general Strategos in military defence. Nevertheless, it is important to see how the term strategy is present in the field of management. Dincer (2007:21) defines strategy as "a process of reorganizing the necessary tools and resources, planning the activities, guiding the operations and providing a competitive advantage to determine objectives which are compatible with changing environmental conditions". Additionally, according to Fitzroy and Hulbert (2005), strategy development obliges the organizations to track which critical variables are changing, to define the speed of the change and guess their probably impact on the business. Overall, the whole concept of strategic management refers to the ability of the organization's management to successfully line up itself with the powers motivating change in the area in which it participates. At the same time, the variable time plays a tremendous role in strategic management, since the only option for managers, in order to win the change is to predict the forthcoming and try to influence it (Drucker, 1968). This article is strongly agreed with the statement of D'Aveni and Gunther (1994: 215) that "companies in hypercompetitive environments succeed or fail based on their ability to manage the process of moving up the escalation ladders, jumping from advantage to advantage". In the same vein Lashley (2008) supported that strategic management in tourism includes action that targets to enhance competitive advantage via a unique standard of services. Having this strong competition in mind, the companies have to use the most appropriate tools in order to sustain the profitability and gain 
competitive advantage.

Strategic management tools can be differentiating among businesses, countries and strategic tasks (Clark, 1997). Additionally, Gunn and Williams' (2007) study supported that enterprises should also use a variety of management tools in their strategic decision making procedure in order to take into advantage all their valid perspectives. Some of the most famous management tools are: financial anlysis, SWOT analysis (Mintzberg et al., 2005), scenario planning (Bush and Nuseibeh, 2006), strategic planning (Bryson, 1988), balanced scorecard (BSC) (Kaplan and Norton 1999), core competence (Banerjee, 2003), benchmarking (Bolat, 2000) and total quality management (TQM).

Despite the fact that strategic management is very important in hospitality businesses, few studies have focused on this issue (Okumus et al., 2017; Koseoglou et al., 2019). Greek literature has limited studies regarding the area of strategic management and more explicitly the strategic management tools. More importantly, there is lack of studies considering hotel enterprises in the context of strategic management tools. The most interesting thing about the present article is that it is written in the middle of COVID - 19 crisis in Greece, as a result we obtained valuable data on how the hotel industry can use the strategic management throughout this unexpected global health crisis.

\section{Methodology}

Regarding the methodology of this paper, this is a literature review based on secondary data. The information was collected from various local governments' publications, publications of international bodies, conference proceedings, company papers and studies, white papers, articles of the tourism industry and marketing journals, and from online books, magazines, and newspapers. The sources of relevant literature investigation derived from popular online bibliographic databases, such as Science Direct, Emerald, EBSCO host, and scientific search engines such as Google Scholar and Scirus, to gain data reliability, suitability, and adequacy. General search engines such as Google have also been examined.

The secondary data were used to help the researchers develop a more comprehensive and holistic view of the role of strategic management practices in facing humanitarian crises, like COVID- 19. The authors have done extensive research on the current literature, hoping to identify existing recovery strategies and make some further recommendations. The selection criteria of these literature sources were based on relevance to the paper's topic, and this research is not exhaustive. It is important to note that since the existing literature is limited, the authors have used literature related to previous cases.

\section{The Review Findings}

The implementation of strategic management occurs through a series of processes related to the understanding of the processes in the context of the organization's environment. Organizations need to focus mainly on their external environment to identify both the risks and opportunities presented to them. In contrast, at the same time, in their internal environment, they must identify the resources and means that allow them to achieve their goals (Johnson et al., 2017).

Formulating the strategy consists of specific stages in which a series of questions are asked to which the organizations must give answers. The first question that any organization needs to answer is what it wants to be. Through its goals and objectives, the organization can find the right answers to this question. The second question the body has to answer is where it is now. This question can be answered through environmental analysis using models such as Porter's five forces and macroenvironment analysis or swot analysis and several other tools that help the organization understand where is related to changes made on the organization's external environment (Okumus et al., 2018).

Once the organisation's management understands what it is about its environment, it must set out to reach its destination and pick up the necessary strategic tools to achieve its targets. Related literature provides several strategic tools, models, and techniques that any organization can choose from. Those can include some more recent devices, such as the blue ocean strategy, to make strategic 
alliances and use the technologies or sustainability to achieve a competitive advantage (Şentürk, 2012).

Of course, besides the use of strategic tools and various techniques to achieve a competitive advantage, a company must be able to use strategic tools to overcome the cases of a crisis. Those may include several turnaround strategies that can turn the situation into an opportunity. Those strategies can use the following tools (Kubickova et al., 2018; Mikulić et al., 2018):

- Focus in market segments which can generate high profitability

- Reducing the operating costs

- Making alliances so to exchange resources, including financial resources and know-how.

However, the case of the COVID- 19 crisis seems to be a different one. Recovery from this recession will doubtless be moderately dissimilar and be contingent on flowing attitudes toward tourism, social assemblies, and the capability to buying. Thus, the authors will try to present which strategic tools hoteliers can use to deal with this crisis and even survive with the second wave of COVID- 19.

The COVID- 19 crisis is universally accepted that it has caused severe problems in how the economies operate. This is something that none can doubt since this virus is global and will exist much more extended than earlier crises. Having in mind the economic problem in 2008, Sars in 2003, $\mathrm{H}_{1} \mathrm{~N}_{1}$ in 2009, and Mers 2015, tourism's influence was more localized and, therefore, more comfortable to deal with. In the current pandemic, the tourism recovery will be a slower, gradual, and non-linear process.

At this stage, it is essential to examine how the hotel industry has responded to the crises mentioned above. In 2007, the world was hit by the most significant economic crisis since the Great Depression in the 1930s. The tourism industry was one of the first victims of that Global Financial Crisis (GFC). However, there was an international effort in recovery from that crisis. Worldwide, recovery energies focused mainly on promoting booking leisure activities and hobbies, leading the hoteliers to upgrade offered facilities/activities and count on satisfying customers' needs. Thus, progressively, tourism was developing from staycations to broaden trips. According to researchers, the GFC has converted traveling in a much more reachable and favorite action for people worldwide (Tourwriter, 2020).

The world was still in an economic crisis when the swine flu ( $\mathrm{H}_{1} \mathrm{~N}_{1}$ influenza) appeared in 2009 and 2010. Economists anticipated that the $\mathrm{H}_{1} \mathrm{~N}_{1}$ pandemic would negatively impact the tourism industry. Still, related research has discovered that the economic impact was minimized due to strategic management and readiness from the past crisis. Mexico is a perfect example since it recovered relatively soon from the $\mathrm{H}_{1} \mathrm{~N}_{1}$ financial crisis (Monterrubio, 2010). Even though this was a challenging economic blow for China's tourism sector, it was not more significant than Mexican tourism since it plays a tremendous role in the Mexican economy.

Mexico lost millions of dollars, and the hotel completeness fell by $50 \%$. However, the country recovered quickly because the Mexican government planned strategies to decrease the economic impact. Thus, it announced creativities to back up the hotel tourism sector and promoted a campaign that advertised the best Mexican journey's end.

In the case of the SARS outbreak in the S.A. Asia in the early 2ooos, according to Henderson \& $\mathrm{Ng}$ (2004), the hotels' response was to follow the rules and guidelines provided by the governments and to use their instinct. There was not any "safe strategy" in such a case. Each hotel unit should examine what resources it had and how it could use them. In Singapore's case, some hotels had to close down for a few months or even for a year not only because of the measures and the lockdown but also because demand had dramatically fallen. Most of the hotels require to have more than $70 \%$ vacancy rate to continue to operate. In such cases, the rate had dropped even to $20 \%$, so the hotel's strategy was to close down to avoid any further costs and save resources for the next year or overall when demand will start to climb again.

A crucial issue is the financial operation of a hotel. The potential of an outbreak of a decease, such as the SARS, means that hotels that want to continue their process during the crisis must adopt a 
strategy that will ensure the clients for their safety (Henderson, 2004). Of course, in the COVID- 19 turmoil, things are much different from any previous outbreak. This is because this is a global epidemic, and still, we are not always confident on how to deal with this virus. What is certain is that in most cases, the hotel industry must work as an open system which reflects and understands the crisis and the changes that it has on its macro-environment. For example, in an environment where tourists cannot fly to a destination, and there is a threat of any hotel guest's contamination, the hotel may have to close down along with the local economy's lockdown. This would mean that the local tourist industry will have to close for a few months. This is not a strategic choice, but the hotels are forced by the government to do so.

Hence, the management of the hotels does not have many choices or strategic tools to use. This is a "one-way" strategy, which is to close down till the lock down is over. Even if there is no lockdown, the vast majority of tourists are not willing to take the risk and flight - if there are flights - hence the hotel has to close down or operate on its minimum resources. Whatever is the strategic choice made to close down or to act in a minimum resource - the hotel industry will have to face huge losses for 2020, which means that it will have to make layoffs or reduce the wages and find ways to cut costs (Hasan \& Aminudin, 2020; Thams et al., 2020).

Overall, the findings mentioned above showed that the previous crises were overcome by adopting governments' measures and rules. Summarising, governments turned to the following actions: locking down the country or some regions, giving financial help packages, and designing national campaigns for advertising and promoting the country. The next part of the article is devoted to recognizing the most practical strategic practices for overcoming the present coronavirus hotel industry crisis.

\section{Discussion - Proposed Strategic Practices to Recover from COVID- 19 Crisis}

This article's main aim is to propose recovering management strategies, which can help the hotel industry respond to this unprecedented crisis. Since there is almost non-existent literature considering this issue, the authors try to present and recommend four strategic management practices: a) the promotion of a safety umbrella, b) the use of technology and innovation, c) the satisfaction of the audience's needs, and empowerment of guests' relationships and d) the financial pillow.

Firstly, an important strategic tool to attract the customers and re-engage with the existing client base is to ensure potential customers about their stay's safety. For the upcoming months, tourists are expected to search not for luxurious hotels or for the hotel with most of the reviews on TripAdvisor, but to search for safety havens with high-level ratings for hygiene and well-being safety. This means that from a strategic perspective, the competitive advantage will not derive from differentiation or cost leadership but from convincing the potential clients that the hotel is clean and safe from COVID- 19. There are two critical aspects here: what hotels do to keep them safe and communicate about what they are doing.

Thus, the recovery of tourism must operate under a "safe travel umbrella." The umbrella will target to put potential guests at ease and ensure a positive, safe experience at the hotel. Public relations will be an essential tool because hotels will have to convince the public about their safety and save their reputation and image in a case of an outbreak within their premises (Karim et al., 2020; Thams et al., 2020). Trust can be derived from safety measures that will be communicated well. For this reason, the umbrella should provide detailed guidance about safety hotel policies adopted to keep their customers and employees safe, as the world emerges from the COVID- 19 pandemic. The umbrella should be well advertised, starting from the hotel website, which will reassure guests that the hotel is taking, and it will take the proper precautions on the property to ensure the safety of workers and clients. All hotels' health protocols should also be displayed in all public areas and guest rooms of the hotels.

Moreover, the cleanliness should be part of the hotel's identity, so it would be an acceptable policy to make it visible. Some practical advice could be arranging a printout on every guest room to give detailed information about how space is cleaned. Also, the hotel can use the website to provide updates 
on when the room is cleaned and what sanitizers are used.

More specifically, the hoteliers should propose new operating standards and protocols that promote both customers' and workers' protection, enhance travelers' confidence, and adapt the appropriate cleaning and hygiene standards. First, the hotel industry should amend employee practices, adjust operations, and restructure public spaces to increase employees' and customers' safety. It is a critical step in preventing virus spread in safe, maintaining a safe distance (three meters) among employees and customers within the hotel. Moreover, strictly sanitation procedures should be followed to hinder the transmission of COVID- 19 disease. The housekeeping staff should wear personal protective equipment and use anti-viral liquids and sprays. Except for the housekeeping services, it will be good practice to establish public self-service sanitation points around the hotel (e.g. antiseptic gel, antibacterial wipes, masks, and gloves). Of course, safety measures will mean that the costs will increase. On some cases, the costs per booking may increase up to $50 \%$ due of the safety measures, including double shifts, buying unique cleaning materials, operating on the $50 \%$ of the capacity, and having the rooms empty for 1-2 days between the bookings so to clean them with exceptional care for et al.-19 (Armstrong et al., 2020; Sigala, 2020). Finally, yet importantly, it is the prevention management policy. Hotel business should implement temperature control systems on guests' arrivals and workers, develop strict guidelines for interacting with outside contractors and suppliers, isolate people with possible signs of illness, and offer health resources to them. According to Armstrong et al. (2020), the hotel must be ready to respond to any case of a guest who is sick from COVID-19. Therefore, the hotel units should develop a specific protocol that will be followed in such a case and define some equipped emergency rooms. Moreover, hotels could assign an emergency number and a point of reference for emergencies.

Another critical strategic practice that should be used is the exploitation of technology and innovation. COVID- 19 pandemic should lead the hoteliers to re-examine their technology investment and re-evaluate the technology strategy to protect their business. The hotel management team should identify technologies that can help them flourish in this critical season. We strongly believe that technology should lead to touchless solutions, which, on the one hand, can limit virus transmission while, on the other hand, can maximize positive travel experiences. An ideal scenario would be the guests' entrance in the hotel without having physical contact with any human or surface until they get into the room. This can be succeeded by mobile Property Management Software (PMS). PMS can promote and satisfy both higher personal cleanliness and social distancing. A mobile PMS can allow customers to avoid human interaction and reduce the risk of contamination. For example, some clients can choose to check-in and check-out by using their mobile devices. At the same time, mobile PMS can be used among the employees, such as housekeeping. The housekeeping team can be effectively coordinated from a tablet. PMS can give vital information about which rooms are occupied, which rooms are cleaned and ready to accommodate customers, and which rooms could be infected.

Moreover, smart kiosks (ID remote scanning and facial recognition) can be installed around the hotel to avoid unnecessary touching on possible contaminated surfaces and invigorate the automatic check-in/out (Dehler, 2020). At the same time, hotels can be innovative by using chatbots ${ }^{1}$ to handle the customers' most frequent questions and provide them information regarding hotel amenities, nearby restaurants, attractions, cultural heritage, transportation, etc. Simultaneously, this digital solution could generate a virtual show of the hotel's basic amenities and services. Lastly, considering the debate among the health researchers who argue whether the COVID- 19 is spreading through the air or not (Financial Express, 2020), special attention should be given at the air quality in the common areas of the hotels. Therefore, hoteliers should invest in clean air equipment to ensure air filtration and hinder the aerosol transmission (Klasko et al., 2020).

Furthermore, another critical aspect that the hotel industry should consider is the possible

${ }^{1}$ A computer program designed to simulate conversation with human users, especially over the Internet. 
clients, the audience. Travelers all around the world are disorganized about their travel ideas. Most people are cancelling their bookings seeking vouchers or refunds, while others are thinking to travel, but are concerned about health and safety. This is the right time to build constructive customer relationships and enhance clients' royalty. It would be wise to give the guests some alternative options for modifying their booked reservations. One option could be the offer of a voucher to reschedule their trip. However, if some clients hesitate to accept vouchers, the hotel could give them full refunds. By doing that, the hoteliers can build trust with their customers to return and book a room in the future. Simultaneously, the hotel should develop a hotel distribution strategy considering the type of travelers that can have until things return to normal. It is essential to count on local tourism to recover and replace lost capital. The location of a hotel could drive the promotion. For example, if a hotel is located in an urban area, it could advertise its business facilities such as meeting rooms and conference halls.

On the contrary, if a hotel is in the countryside, it would focus on how it will leisure the guests. It is significant to inform the audience via the web site or emails for all the latest booking cancelations and safety and prevention plans. This could be more practically understandable by creating and sharing a video, informing potential guests about the new safety policies (umbrella).

Lastly, the hoteliers should take into consideration the "financial pillow." According to the Organisation for Economic Cooperation and Development (2020), governments have been taking extraordinary measures to respond and overcome the COVID- 19 crisis in most countries. Governments' exertions include a variety of practices to guarantee companies' existence. Some of the rules are the following: communication campaigns, economic survival package, tax relief, grants and guarantees, loans, etc. Despite the government above's support, the hoteliers should reconsider various hotel expenses, including fixed costs, marketing, and payroll. It is very significant to have budget adaptability. When the crisis is still present, it is better for the hoteliers to make some modifications and limit the budget effects conventionally. It will also be essential to create an intelligent plan to cope with matters such as cancellations, distribution channels, and reservations.

Nevertheless, the case of COVID- 19 indicated that the most significant strategic plan should be the hotel industry's effort to operate with a more considerable profit margin and always to have some emergency funds. The hotel industry, like many other industries, is working on very narrow profit margins. A tremendous example to avoid is what happened on many airlines due to their thin profit margins, which forced them to go bankrupt due to flights' cancellation after the 9/11 terrorist attacks. This means that a strategic tool for survival could be to have a "financial pillow," which will allow the hotels to operate for few months even if they are closed or have limited bookings (Fahlenbrach et al., 2020).

\section{Conclusions}

In the middle of the COVID- 19 pandemic, someone can forget that the international economy and tourism sector have lived quite similar situations in the near past. Despite the nature of the threat, whether it is a health pandemic or economic crisis or natural tragedy or terrorism attack, the tourism industry is tremendously forceful and is unique in overcoming these events. The history shows that the tourism sector can take advantage of any crisis and be reborn. The present research looks forward to giving a hand of help to all hotel industries and support their efforts for recovery.

This paper discussed the strategic choices and tools, which can help the hotel industry acknowledge how to cope with the current situation. The COVID- 19 crisis has resulted not only in the dramatic reduction of demand for hotel services but also on lockdowns. This brings the need to reconsider the strategic tools that the hotel industry can use. Despite the lack of empirical evidence, it seems that there are some strategic choices such as to focus on ensuring safety for the guests, pay attention to new technology, strengthen guest relationships and satisfy clients' needs but also to create a "financial pillow" to recover from this crisis and even to cope with the second wave of COVID- 19.

Overall, it is recommended that future research seeks to investigate successful cases of hotels, which have recovered by the COVID- 19 crisis to indicate the most applied effective strategies. It will 
be of great importance if this article's proposed strategic management practices find support from future empirical findings. This could add to the current literature and enrich our knowledge of how the hotel industry can overcome any economic crisis.

Tourism is an essential part of many national economies. Looking at the future, the recovery measures put in place today will build a more sustainable and more robust tourism economy of tomorrow. This global pandemic is an opportunity to reconsider tourism for the future.

\section{References}

Abu Bakar, A.H., Asim Tufil, M., Nizam Yosof, M., \& Virgiyanti, W. (2011). Implementation of strategic management practices in the Malaysian Construction Industry. Pak. J. Commer. Soc.Sci., 5(1), 140-154.

Aktan, C.C. (1998). Gelecegi Kazanmanin Yolu: Stratejik Yonetim. Journal of Yeni Turkiye, 335-342.

Ansoff, H.I., Kipley, D., Lewis, A.O., Helm-Stevens, R., \& Ansoff, R. (2018). Implanting strategic management. London: Springer.

Armstrong, P., Armstrong, H., Choiniere, J., Lowndes, R., \& Struthers, J. (2020). Re-imagining long-term residential care in the COVID- 19 crisis. Ottawa, ON: Canadian Centre for Policy Alternatives.

Benerjee, P. (2003). Resource Dependence and Core Competence: Insights from Indian Software Firms. Technovation, 23, 251-263.

Bolat, T. (2000). Toplam Kalite Yonetimi, Istanbul: Beta Publishing.

Bryson, J.M. (1988). A Strategic Planning Process for Public and Non-Profir Organisations. Long Rang Planning, 21(1), $73-81$.

Bush, D., \& Nuseibeh, B. (2006). Requirements Engineering Research in Some Future Worlds: An Exercise in Scenario Planning. $14^{\text {th }}$ IEEE International Requirements Engineering Conference.

Clark, N.D. (1997). Strategic Management Tool Usage: A Comparative Study. Strategic Change, 6, 417-427.

D’ Aveni, R.A., \& Gunther, R. (1994). Hyper Competition-Managing The Dynamics of Strategic Maneuvering. USA: The Free Press.

Dehler, N. (2020). COVID- 19 and Hospitality: Re-evaluating Your Hotel Technology Strategy to Prepare for a New Normal Post-Recovery. [Online]. Available at: https://www.stayntouch.com/resources/articles/COVID- 19 and-hospitality-re-evaluating-your-hotel-technology-strategy-to-prepare-for-a-new-normal-post-recovery/

Dincer, O. (2007). Stratijik Yonetim ve Isleme Politikasi, $8^{\text {th }}$ edition. Istanbul: Alfa Publishing.

Drucker, P.F. (1968). The Age Od Discontinuity: Guidelines to our Changing Society, U.S.: Transaction Publishers.

Eren, E. (2006). Stratjik Yonetim. Eskisehir: Anadolu Universitesi Publishing.

Fahlenbrach, R., Rageth, K., \& Stulz, R.M. (2020). How Valuable is Financial Flexibility when Revenue Stops? Evidence from the COVID-19 Crisis (No. w27106). National Bureau of Economic Research.

Financial Express (2020). Can coronavirus spread through air? Hundreds of experts make COVID- 19 is airborne claim. Online Financial Express. [Online]. Available at: Available at: https://www.financialexpress.com/lifestyle/health/is-coronavirus-spreading-through-air-experts-claimCOVID- 19 -is-airborne/2014364/

Fitzroy, P. \& Hulbert, J.M. (2005). Strategic Management-Creating Value in a Turbulent Word. UK: John Wiley \& Sons Inc.

Gunn, R., \& Williams, W. (2007). Stratigic Tools: An Empirical Investigation Into Strategy in Practice in the UK. Strategic Change, 16, 201-216.

Hasan, M.R., \& Aminudin, N. (2020). Destination Management Organisation Managers' Behavioural Intentions towards Crisis Planning in Malaysia. In Travel and Tourism: Sustainability, Economics, and Management Issues (pp. 141-159). Springer, Singapore.

Henderson, J.C. (2004). Managing a health-related crisis: SARS in Singapore. Journal of Vacation Marketing, 10(1), 67-77.

Henderson, J.C., \& Ng, A. (2004). Responding to crisis: severe acute respiratory syndrome (SARS) and hotels in Singapore. International Journal of Tourism Research, 6(6), 411-419.

Johnson, G., Whittington, R., Scholes, K., Angwin, D.N., \& Regnér, P. (2017). Exploring strategy (No. 11th e). NJ: Pearson.

Kaplan, R.S., \& Norton, D.P. (1999). Balanced Scorecard: Sirket Stratejisini Eyleme Domusturmek. Istanbul: Sistem Publishing.

Karim, W., Haque, A., Anis, Z., \& Ulfy, M.A. (2020). The movement control order (mco) for COVID- 19 crisis and its impact on tourism and hospitality sector in Malaysia. International Tourism and Hospitality Journal, 3(2), $1-7$. 
Klasko, S., Gleason, J.L., \& Hoad, M. (2020). What hotels must learn from hospitals for the new reality of tourism. [Online]. Available at: https://www.weforum.org/agenda/2020/o5/lessons-from-hospitals-to-the-hospitalitysector-COVID- 19 /

Köseoglu, M.A., Law, R., Okumus, F., Barca, M., \& Dogan, I.C. (2019). Evolution of Strategic Management Research Lines in Hospitality and Tourism. J. Hosp. Mark. Manag., 28, 690-710.

Kubickova, M., Kirimhan, D., \& Li, H. (2019). The impact of crises on hotel rooms' demand in developing economies: The case of terrorist attacks of $9 / 11$ and the global financial crisis of 2008. Journal of Hospitality and Tourism Management, 38, 27-38.

Lashley, C. (2008). Marketing hospitality and tourism experiences. In Handbook of Hospitality Marketing Management; Oh, H., Pizam, A., Eds.; Elsevier Ltd.: Oxford, UK, 3-31.

Mason, P., Grobowski, P., \& Du, W. (2005) 'Severe acute respiratory syndrome, tourism and the media', International Journal of Tourism Research, Vol. 7, No. 1, pp.11-21.

Mather, S., Viner, D., \& Todd, G. (2005) Climate and policy changes: Their implications for international tourism flows. In C. M. Hall and J. Higham (Eds.), Tourism, recreation and climate change (pp. 63-85), Channel View Publications, Clevedon.

Mikulić, J., Sprčić, D.M., Holiček, H., \& Prebežac, D. (2018). Strategic crisis management in tourism: An application of integrated risk management principles to the Croatian tourism industry. Journal of destination marketing $\mathcal{E}$ management, $7,36-38$.

Mintzberg, H., Ahlstrand, B., \& Lampel, J. (2005). Strategy Safari: A Guided Tour Through the Wilds of Strategic Management. $10^{\text {th }}$ Edition. New York: Free Press.

Monterrubio. J.C. (2010) Short-term economic impacts of influenza A ( $\left.\mathrm{H}_{1} \mathrm{~N}_{1}\right)$ and government reaction on the Mexican tourism industry: An analysis of the media. International Journal of Tourism Policy, 3(1), 1-15.

Okumus, F., Altinay, L., Chathoth, P., \& Koseoglu, M.A. (2019). Strategic management for hospitality and tourism. London: Routledge.

Okumus, F., Köseoglu, M.A., Morvillo, A., \& Altin, M. (2017). Scientific progress on strategic management in hospitality and tourism: A state-of-the-art. Tour. Rev., 72, 261-273.

Organisation for Economic Cooperation and Development (2020). Tourism Policy Responses to the coronavirus (COVID- 19). [Online]. Available at: https://read.oecd-ilibrary.org/view/?ref=124_1249847uf8nm95se\&title=COVID-19_Tourism_Policy_Responses

Page, S., \& Connell, J. (2006) Tourism: A modern synthesis (2 ed.), Thomson, London.

Ryan, C. (2003) Recreational tourism: Demands and impacts. Channel View Publications, Clevedon.

Şentürk, F.K. (2012). A study to determine the usage of strategic management tools in the hotel industry. Procediasocial and Behavioural sciences, 58, 11-18.

Sigala, M. (2020). Tourism and COVID- 19 : impacts and implications for advancing and resetting industry and research. Journal of Business Research, 117, 312-321.

Thams, A., Zech, N., Rempel, D., \& Ayia-Koi, A. (2020). An initial assessment of economic impacts and operational challenges for the tourism \& hospitality industry due to COVID- 19 (No. 2/2020). IUBH Discussion PapersTourisms \& Hospitality.

Tourwriter (2020). The travel industry is resilient: Historical events and how tourism has bounced back. [Online]. Available at: https://www.tourwriter.com/travel-software-blog/COVID-19 -pt1/

World Travel and Tourism Council (2020). What is the future of travel and tourism after COVID-19 ? Financial Times Global Economic Crisis - What Now? Global Digital Conference, 12-14 May.

Kaplan, R. \& Norton, D. (1996). The balanced scorecard. Translating strategy into action, Harvard Business School, Boston. 